\title{
Chemical pattern of brazilian apples. A chemometric approach based on the Fuji and Gala varieties
}

\author{
Padrão químico da maçã brasileira. Uma abordagem quimiométrica baseado nas variedades Fuji e Gala
}

\author{
Renato Giovanetti VIEIRA ${ }^{1,5 *}$, Rosilene Aparecida PRESTES ${ }^{1,4}$, \\ Frederico DENARDI ${ }^{2}$, Alessandro NOGUEIRA ${ }^{1}$, Gilvan WOSIACKI ${ }^{1,3}$
}

\begin{abstract}
The chemical composition of apple juices may be used to discriminate between the varieties for consumption and those for raw material. Fuji and Gala have a chemical pattern that can be used for this classification. Multivariate methods correlate independent continuous chemical descriptors with the categorical apple variety. Three main descriptors of apple juice were selected: malic acid, total reducing sugar and total phenolic compounds. A chemometric approach, employing PCA and SIMCA, was used to classify apple juice samples. PCA was performed with 24 juices from Fuji and Gala, and SIMCA, with 15 juices. The exploratory and predictive models recognized $88 \%$ and $64 \%$, respectively, as belonging to a mixed domain. The apple juice from commercial fruits shows a pattern related to cv. Fuji and Gala with boundaries from 0.18 to 0.389 g. $100 \mathrm{~mL}^{-1}$ (malic acid), from 8.65 to $15.18 \mathrm{~g} .100 \mathrm{~mL}^{-1}$ (total reducing sugar) and from 100 to 400 mg.L $\mathrm{L}^{-1}$ (total phenolic compounds), but such boundaries were slightly shorter in the remaining set of commercial apple juices, specifically from 0.16 to 0.36 g. $100 \mathrm{~mL}^{-1}$, from 9.25 to 15.5 g. $100 \mathrm{~mL}^{-1}$ and from 180 to $606 \mathrm{mg} . \mathrm{L}^{-1}$ for acidity, reducing sugar and phenolic compounds, respectively, representing the acid, sweet and bitter tastes.

Keywords: chemometry; chemical descriptor; pattern recognition.
\end{abstract}

\section{Resumo}

A composição química de sucos de maçã pode ser usada para diferenciar as variedades de mesa das industriais. Fuji e Gala têm características químicas que podem ser usadas para esta classificação. Métodos multivariados relacionam descritores químicos com a categoria da variedade de maçã. Três principais descritores do suco de maçã foram selecionados: ácido málico, açúcar redutor total e compostos fenólicos. Uma abordagem quimiométrica, empregando PCA e SIMCA, foi usada para classificar amostras de sucos de maçã. PCA foi realizado com 24 amostras de suco de Fuji e Gala, e SIMCA, com 15 sucos. Os modelos exploratórios e preditivos reconheceram $88 \%$ e $64 \%$, respectivamente, como pertencentes a um domínio misto. Os sucos de maçã de frutas comerciais mostraram um padrão com as cultivares Fuji e Gala com limites de 0,18 a 0,389 g. $100 \mathrm{~mL}^{-1}$ (ácido málico), de 8,65 a 15,18 g.100 mL (açúcar redutor total) e de 100 a 400 mg.L $\mathrm{L}^{-1}$ (compostos fenólicos), mas tais limites foram levemente menores no conjunto restante de sucos de maçãs comerciais, especificamente de 0,16 a 0,36 g. $100 \mathrm{~mL}^{-1}$, 9,25 a 15,5 g.mL $\mathrm{mL}^{-1}$ e 180 a 606 mg.L $\mathrm{L}^{-1}$ para acidez, açúcar redutor total e compostos fenólicos, respectivamente, representando os sabores ácido, doce e amargo.

Palavras-chave: quimiometria; descritores químicos; reconhecimento de padrões.

\section{Introduction}

The production of apples actually began in the early 1970s with cultivars adapted to the highland locations in the Southern States of Brazil. The economic viability was then explained to the people involved with investments in the apple business, focusing on the technological intensification on the Fuji and Gala varieties, which represent $93 \%$ of the apple production (KREUTZ et al., 2002). The remaining 7\% of apple production comprises many precocious varieties, most of them with a very low chilling requirement and harvesting time much earlier than cv. Gala, which currently represents good options to small fruit growers and attractive prices. In a world-wide perspective, Gala and Fuji have been ranked as the $3^{\text {rd }}$ and $4^{\text {th }}$ apples produced, in metric ton, only behind Golden Delicious $\left(1^{\text {st }}\right)$ and Delicious $\left(2^{\text {nd }}\right)$ (WORLD APPLE REVIEW, 2008).

Fuji and Gala apples were brought to Brazil in the 1960s, the former from Japan and the latter from New Zealand (WOSIACKI et al., 2002). Even in the colder regions of Southern Brazil, the chilling requirement for these apples is not satisfied in areas below an altitude of $1.300 \mathrm{~m}$, where chemical treatments are needed to break bud dormancy. For cv. Fuji, even with good flowering, cropping and a non-biannual bearing, the fruit quality is better above an altitude of $1.300 \mathrm{~m}$. In contrast, Gala has good

${ }^{1}$ Departamento de Engenharia de Aimentos, Universidade Estadual de Ponta Grossa - UEPG, Av. Carlos Cavalcanti, 4748, CEP 84030-900, Ponta Grossa, PR, Brasil

E-mail: gilvan.wosiacki@pesquisador.cnpq.br; alessandro.nogueira@pesquisador.cnpq.br; raprestes@yahoo.com.br; renatogiovanetti@gmail.com

${ }^{2}$ Empresa de Pesquisa Agropecuária e Extensão Rural de Santa Catarina, Rua Alcides Tombini, 33, CEP 89500-000, Paraíso, Caçador, SC, Brasil

${ }^{3}$ CNPq-PQ1, Departamento de Engenharia de Alimentos, Universidade Estadual de Ponta Grossa, Av. Carlos Cavalcanti, 4748, CEP 84030-900, Ponta Grossa, PR, Brasil

${ }^{4}$ CNPq-PDJ, Departamento de Engenharia de Alimentos, Universidade Estadual de Ponta Grossa, Av. Carlos Cavalcanti, 4748, CEP 84030-900, Ponta Grossa, PR, Brasil

${ }_{5}$ CNPq-AT, Departamento de Engenharia de Alimentos, Universidade Estadual de Ponta Grossa, Av. Carlos Cavalcanti, 4748, CEP 84030-900, Ponta Grossa, PR, Brasil

${ }^{*}$ Corresponding author 
performance even at lower elevations. According to Henschke (1994), more studies must be conducted to improve the main varieties concerning appearance, amount of juice, size, shape, storage capacity and to reach a yield of 25 ton.ha ${ }^{-1}$ of high quality apples aiming to export them to other places, within Brazilian borders or overseas. Harvested commercial apples are driven through a complex selection and physical classification system where $70 \%$ are classified as table fruit and, of the remaining fruit, $10 \%$ is classified to be waste (negative costs) and $20 \%$ is damaged but healthy fruit, which constitutes the actual Brazilian industrial raw material. The classification of apples for commercialization was made by taking into consideration sensorial aspects such as acid, sweet and bitter tastes. The amounts of malic acid and total phenolic compounds have been used for the commercial classification of apples, usually as bitter sweet, but such praxis does not include the total reducing sugar content.

The use of multivariate methods to establish the relationship between the independent continuous variable and the categorical variable is becoming widespread (BARROS NETO; SCARMÍNIO; BRUNS, 2006; BLANCO-GOMIS et al., 1998).

Exploratory techniques such as Principal Component Analysis (PCA) may be used to select the main continuous descriptors of a categorical variable and, with the auto-scaled data, may provide an exploratory model. Classificatory techniques such as Soft Independent Modeling of Class Analogy (SIMCA) may be used to classify similar categorical variables (BARROS NETO; SCARMÍNIO; BRUNS, 2006). AlonsoSalces et al. (2005) used the pattern recognition analysis of the apple polyphenolics to classify them by their maturity state. Blanco-Gomis et al. (1998) discriminated apple juices clarified by micro-filtration or by ultra-filtration by an exploratory HCA to select the best descriptor, using PCA to quantify the components, and LDA (Linear Discriminant Analysis) and KNN to classify the juices with $100 \%$ correctness. González, Peña-Mendez (2000) were able to differentiate must and wine through chemometric analysis such as Discriminant Analysis (DA), PCA, Biplot (BA) and Factor Analysis (FA). Molfetta et al. (2005) studied the structure - activity relationship (SAR) of quinone compounds with biological activity by employing PCA, HCA, SIMCA and KNN.

A multivariate analyses approach may be useful to classify apple varieties according to a few independent chemical descriptors of apple juices. The main purpose of this article was to establish the chemical pattern of Brazilian commercial apples according to the selected chemical descriptors of the Fuji and Gala varieties by employing multivariate methods.

\section{Materials and methods}

\subsection{Materials}

Samples of commercial and experimental varieties of apple were collected during many seasons, since 1992 to the present, from many places in the Southern States of Brazil. Their juices were analyzed and the results stored in the GTM database. From this database, the chemical descriptors of many samples from Fuji and Gala juices were recovered for an initial screening to select the main descriptors for juice classification. Then, the chemical descriptors of 12 samples from both varieties, as well from 15 authentic apple juices obtained from commercial varieties, were recovered in order to test the capacity of the predicting model. Usually, 5-10 kg of sample were processed to obtain depectinized juice. Stabilized apple juices were used for further analyses after a qualitative paper filtration, when necessary. Pectinolytic enzymes samples (Pectinex 3 XL NOVO Nordisk do Brazil) used for apple juice clarification were danated by LNF Ltd., Bento Gonçalves, RS. Chemical products used in the analyses or in the experiments were also from quality pro analysis.

\subsection{Methods}

\section{Processing}

Apple juice was obtained by mechanical pressure according to the protocol described by Wosiacki et al. (1989), depectinized in a hot step in a water bath $\left(2\right.$ hours, $\left.45^{\circ} \mathrm{C}\right)$, filtered through paper, bottled, closed and stabilized through freezing.

\section{Analysis}

Total Soluble Solids (TSS) were determined in a refractometer adjusted to $20^{\circ} \mathrm{C}$ (INSTITUTO..., 1985). The content of glucose (GLC) was determined with a glucose oxidase kit assay and the amount of fructose (FRU) was then calculated as the remnant from reducing sugar. The amount of sucrose (SAC) was determined as the difference between total reducing sugar and reducing sugar (SOMOGYI, 1945; NELSON, 1944). The total titrable acidity (TTA) was determined with $0.1 \mathrm{M} \mathrm{NaOH}$ and expressed as malic acid (MAL) in g. $100 \mathrm{~mL}^{-1}$. The total phenolic compounds (TPC) were determined through the Folin-Ciocalteau reagent (TANNER; BRUNNER, 1979 ) and expressed as (+) catechin, in mg. $\mathrm{L}^{-1}$. The ratio was calculated by total reducing sugar/total titrable acidity as an adimensional figure. The Descriptive Statistic Analysis of the chemical descriptors was made by employing the Statistic 7.0 software. The Principal Component (PCA) was employed in the exploratory analysis and the pattern recognition method Soft Independent Modeling of Class Analogy (SIMCA) was used to classify the apple varieties (categorical) according to their relationship with selected chemical descriptors (continuous variable). The auto scaled processing allowed the results to be compared to each other at the same scale (BARROS NETO; SCARMÍNIO; BRUNS, 2006). PCA and SIMCA were performed with Pirouette $^{\circledast}$ software, version 4.1 (Infometrix).

\section{Results and discussion}

Table 1 shows the main chemical attributes of 'Fuji' and 'Gala' apple juice samples, recovered from the database maintained by the GTM (Apple Working Team) at Ponta Grossa State University. All the independent chemical attributes were 
tested aiming to select the most interesting ones to be used as a discriminative attribute, or chemical descriptor.

All attributes were submitted to exploratory analyses and those with greater statistic potential, for further pattern recognition methods, were selected as chemical descriptors. The main independent descriptors were total malic acid (MAL), total reducing sugar (TRS) and total phenolic compound (TPC) contents. These descriptors represent the acid taste, the sweetness or sweet taste and bitterness or bitter mouth feeling. A relative descriptor, namely ratio, a function of the total reducing sugar and total malic acid contents, ratio $[\mathrm{r}=\mathrm{f}$ (TRS, MAL)], was left together due to its utilization in the first step of apple characterization.
A group of 24 authentic 'Fuji' and 'Gala' apple juices, whose descriptors are shown in Table 2, was used in the exploratory experiments with multivariate methods. The values found for both fruit cultivars were close, but they suggest that Fuji (MAL $=0.275 \pm 0.045$ g. $100 \mathrm{~mL}^{-1}$; TRS $\left.=12.52 \pm 1.44 \mathrm{~g} .100 \mathrm{~mL}^{-1} ; \mathrm{TPC}=255 \pm 77 \mathrm{mg} \cdot \mathrm{L}^{-1}\right)$ is sweeter than Gala $\left(\mathrm{MAL}=0.278 \pm 0.056 \mathrm{~g} .100 \mathrm{~mL}^{-1}\right.$; TRS $=11.30 \pm 1.64$ g. $\left.100 \mathrm{~mL}^{-1} ; \mathrm{TPC}=317 \pm 116 \mathrm{mg} . \mathrm{L}^{-1}\right)$, which has a higher acidity and bitterness.

Although the results of total phenolic compounds from samples Gala 13 and Gala 21 seem to be quite different from the Gala set, these samples were not excluded by the Q-test (SHUGAR; BALLINGER, 1996).

Table 1. Main physical-chemical attributes of apple juices.

\begin{tabular}{|c|c|c|c|c|c|c|c|c|c|c|c|c|}
\hline \multirow[t]{2}{*}{ Analysis } & \multicolumn{6}{|c|}{ Fuji } & \multicolumn{6}{|c|}{ Gala } \\
\hline & $\mathrm{N}^{*}$ & Min & Mean & Max & Std. Dev. & Var & $\mathrm{N}$ & Min & Mean & $\operatorname{Max}$ & Std. Dev. & Var \\
\hline Malic acid, g.100 $\mathrm{mL}^{-1}$ & 40 & 0.136 & 0.249 & 0.434 & 0.082 & 0.007 & 55 & 0.123 & 0.285 & 0.401 & 0.058 & 0.003 \\
\hline Reducing Sugar, g.100 mL mL $^{-1}$ & 40 & 6.46 & 10.36 & 15.31 & 2.09 & 4.37 & 55 & 6.30 & 8.70 & 14.65 & 1.90 & 3.60 \\
\hline Total reducing sugar, g.100 mL $\mathrm{mL}^{-1}$ & 39 & 10.17 & 12.75 & 16.29 & 1.56 & 2.44 & 54 & 9.00 & 11.06 & 15.04 & 1.51 & 2.28 \\
\hline Ratio & 24 & 24.82 & 67.10 & 113.92 & 28.62 & 819.22 & 33 & 25.52 & 40.52 & 56.54 & 8.60 & 73.89 \\
\hline Total phenolic compounds, mg. $\mathrm{L}^{-1}$ & 37 & 130 & 254 & 404 & 69 & 4,716 & 52 & 124 & 297 & 544 & 98 & 9,578 \\
\hline Fructose, g.100 mL $\mathrm{mL}^{-1}$ & 33 & 3.33 & 7.36 & 9.84 & 1.63 & 2.64 & 48 & 4.87 & 6.99 & 9.99 & 1.54 & 2.36 \\
\hline Glucose, g.100 mL $\mathrm{m}^{-1}$ & 34 & 0.99 & 2.98 & 5.20 & 1.11 & 1.23 & 49 & 0.82 & 1.46 & 2.29 & 0.29 & 0.08 \\
\hline Sucrose, g.100 mL $\mathrm{mL}^{-1}$ & 38 & 0.52 & 2.62 & 5.62 & 1.22 & 1.50 & 53 & 0.55 & 2.52 & 5.95 & 0.96 & 0.92 \\
\hline
\end{tabular}

Table 2. Chemical descriptors of 24 apple juices from cvs. Fuji and Gala.

\begin{tabular}{|c|c|c|c|c|c|c|}
\hline Code & Variety & Crop & $\begin{array}{l}\text { Malic acid } \\
\left(\mathrm{g} .100 \mathrm{~mL}^{-1}\right)\end{array}$ & $\begin{array}{l}\text { Total reducing sugar } \\
\quad\left(\mathrm{g} .100 \mathrm{~mL}^{-1}\right)\end{array}$ & $\begin{array}{l}\text { Total phenolic compounds } \\
\left(\mathrm{mg} \cdot \mathrm{L}^{-1}\right)\end{array}$ & Ratio \\
\hline 1 & Fuji & 1986-1987 & 0.287 & 15.80 & 404 & 55.052 \\
\hline 2 & Fuji & 1990-1991 & 0.250 & 12.04 & 200 & 48.14 \\
\hline 3 & Fuji & 1991-1992 & 0.330 & 13.37 & 200 & 40.52 \\
\hline 4 & Fuji & 1993-1994 & 0.220 & 12.08 & 130 & 54.91 \\
\hline 5 & Fuji & 1994-1995 & 0.265 & 12.29 & 195 & 46.38 \\
\hline 6 & Fuji & 1995-1996 & 0.310 & 12.50 & 261 & 40.32 \\
\hline 7 & Fuji & $2000-2001$ & 0.290 & 12.04 & 260 & 41.52 \\
\hline 8 & Fuji & 2001-2002 & 0.310 & 11.46 & 259 & 36.97 \\
\hline 9 & Fuji & $2002-2003$ & 0.346 & 10.17 & 374 & 29.39 \\
\hline 10 & Fuji & 2004-2005 & 0.196 & 13.59 & 309 & 69.60 \\
\hline 11 & Fuji & 2005-2006 & 0.238 & 13.65 & 228 & 80.05 \\
\hline 12 & Fuji & 2006-2007 & 0.259 & 11.33 & 240 & 43.92 \\
\hline 13 & Gala & 1986-1987 & 0.317 & 15.04 & 544 & 47.45 \\
\hline 14 & Gala & 1990-1991 & 0.315 & 12.70 & 200 & 40.32 \\
\hline 15 & Gala & 1991-1992 & 0.330 & 12.00 & 200 & 36.36 \\
\hline 16 & Gala & 1993-1994 & 0.200 & 10.62 & 222 & 53.10 \\
\hline 17 & Gala & 1994-1995 & 0.162 & 10.62 & 222 & 65.76 \\
\hline 18 & Gala & $1999-2000$ & 0.320 & 11.11 & 403 & 34.72 \\
\hline 19 & Gala & $2000-2001$ & 0.312 & 10.33 & 309 & 33.15 \\
\hline 20 & Gala & 2001-2002 & 0.313 & 10.56 & 293 & 33.78 \\
\hline 21 & Gala & $2002-2003$ & 0.250 & 9.32 & 493 & 37.28 \\
\hline 22 & Gala & 2004-2005 & 0.249 & 12.86 & 392 & 51.60 \\
\hline 23 & Gala & 2005-2006 & 0.329 & 11.21 & 238 & 35.19 \\
\hline 24 & Gala & 2006-2007 & 0.240 & 9.20 & 291 & 38.33 \\
\hline
\end{tabular}


The chemical descriptors of a set with 15 authentic commercial varieties of apple juices, selected to verify the effectiveness of the model, are shown in Table 3 . Average figures of the selected descriptors (malic acid $=0.295 \pm 0.087 \mathrm{~g} .100 \mathrm{~mL}^{-1}$ [29.7\%], total reducing sugar $=12.12 \pm 1.52 \mathrm{~g} .100 \mathrm{~mL}^{-1}[12.57 \%]$, total phenolic compounds $\left.=349 \pm 131 \mathrm{mg} . \mathrm{L}^{-1}[37.59 \%]\right)$ reflect a more acid and bitter set, although intermediate in sweetness.

According to Lea (1995) and Lea and Drilleau (2003), the scatter plot of the amount of malic acid and total phenolic content (Table 2) may define four groups as the former separate the sweet $\left(<0.45 \mathrm{~g} .100 \mathrm{~mL}^{-1}\right)$ from the sharp $\left(>0.45 \mathrm{~g} .100 \mathrm{~mL}^{-1}\right)$ and the latter, the bitter $\left(>200 \mathrm{mg} \cdot \mathrm{L}^{-1}\right)$ from the sweet $\left(<200 \mathrm{mg} \cdot \mathrm{L}^{-1}\right)$. The four apple groups are named sweet, sharp, bitter sweet and bitter sharp by these criteria. Schobinger (1995) used the central criterion but stretched the boundaries, creating domains with expressions such as "very low acid - flat", "very high acid - sour", for instance, and proposed a circular area inside the diagram where the combination was harmonious. It must be considered that the enzyme-treated apple juices do have lower amounts of phenolic compounds and so the process should be kept the same (SCHOBINGER, 1995; NOGUEIRA et al., 2003).

Figure 1a shows the position of each of the 24 samples of apple juice from the set of authentic Fuji and Gala varieties concerning the malic acid and phenolic compound coordinates. The chemical domain of these commercial apples is defined within the limits from 0.15 to $0.35 \mathrm{~g} .100 \mathrm{~mL}^{-1}$ of malic acid and from 100 to $600 \mathrm{mg} . \mathrm{L}^{-1}$ of total phenolic compounds, and so they can be classified as sweet and bittersweet apples. However, neither the 'Fuji' nor the 'Gala' domains can be discriminated in such a classification procedure. Likewise, Figure $1 \mathrm{~b}$ shows the position of each of the 15 authentic samples of commercial apple juices, and it was confirmed that they fall in the same area, with the exception of Royal Gala [47], Princesa [21] and Imperial Gala [46], which are slightly more acidic than $0.35 \mathrm{~g} .100 \mathrm{~mL}^{-1}$.
Czelusniak et al. (2003) analyzed fruits harvested in a commercial orchard including fruits from producer and pollinator trees during the 2001/2002 season. Among 27 apple juices, one was classified as sweet; 14 as bittersweet within the boundaries of this experiment; three were found to contain more phenolic compounds; and ten were categorized as bitter sharp. The first 15 samples were apples with commercial appeal. Table apples are usually qualified as bittersweet (SCHOBINGER et al., 1995). According to these criteria, Paganini et al. (2004), qualified five apples as bittersweet and two as sweet from seven commercial apple varieties harvested in the 2003/2004 season. Fertonani et al. (2006) reported that the samples of 'Gala,' 'Fuji' and 'Joaquina' they used to extract pectin from pomaceae were indeed qualified as bitter. Nogueira et al. (2006) reported that from 14 samples of apple juices, comprising four commercial and ten advanced selections, five were qualified as bitter sharp and could be used as raw material and the others as bittersweet, obviously table apples.

The ratio between total reducing sugar and malic acid provides a descriptor for the quality of apple and the adimensional value of 20 separates the industrial from the commercial (LEA, 1995). Figures $2 \mathrm{a}$ and $2 \mathrm{~b}$ show that all apples listed in Tables 2 and 4 are table fruits and do not fit any technological utilization. This experiment states that none of the samples tested falls in the domain of industrial set of apples, considering their own profile of quality, completely clustered in the domain of commercial apples. This can be extended to the conclusion that the apples used for juice processing in Brazil are, indeed, of commercial quality and they do not fit any industrial pattern. But, while working with 27 samples of apple varieties (including three producers and pollinizers), Czelusniak et al. (2003) proved that, although many components of this set belong to the commercial category, they have been classified as industrial. The highest is 'Einshemer,' with a high malic acid content - around 1.0 g. $100 \mathrm{~mL}^{-1}$, and Rainha,

Table 3. Chemical descriptor of 15 apple juices from commercial varieties

\begin{tabular}{|c|c|c|c|c|c|}
\hline Code & Variety & $\begin{array}{l}\text { Malic acid } \\
\left(\text { g.100 } \mathrm{mL}^{-1}\right)\end{array}$ & $\begin{array}{l}\text { Total reducing sugar } \\
\quad\left(\text { g. } 100 \mathrm{~mL}^{-1}\right)\end{array}$ & $\begin{array}{l}\text { Total phenolic compounds } \\
\left(\mathrm{mg} \cdot \mathrm{L}^{-1}\right)\end{array}$ & Ratio \\
\hline 25 & Catarina & 0.265 & 14 & 250.417 & 52.819 \\
\hline 26 & Condessa & 0.177 & 11.264 & 447.495 & 63.746 \\
\hline 27 & Daiane & 0.286 & 13.788 & 397.934 & 48.151 \\
\hline 28 & Eva & 0.403 & 10.217 & 244.937 & 26.214 \\
\hline 29 & Golden delicious & 0.312 & 10.533 & 535.082 & 33.757 \\
\hline 30 & Imperatriz & 0.250 & 14.711 & 460.566 & 58.767 \\
\hline 31 & Joaquina & 0.194 & 13.044 & 250.545 & 67.776 \\
\hline 32 & Kiko 8 & 0.227 & 12.944 & 257.8 & 57.001 \\
\hline 33 & Mollie's Delicious & 0.260 & 11.267 & 523.312 & 43.799 \\
\hline 34 & NF Golden & 0.324 & 10.236 & 381.281 & 31.607 \\
\hline 35 & Red Delicious & 0.206 & 13.522 & 518.689 & 66.071 \\
\hline 36 & Royal Gala & 0.270 & 10.356 & 318.033 & 38.372 \\
\hline 37 & Sansa & 0.337 & 12.889 & 364.204 & 38.207 \\
\hline 38 & Princesa & 0.456 & 11.06 & 114 & 10.307 \\
\hline 39 & Eva & 0.454 & 11.982 & 183.5 & 26.897 \\
\hline
\end{tabular}


Primicia, and Princesa, with malic acid contents of $0.64,0.46$ and 0.42 , respectively.

These approaches to classify apples do not give any direct information concerning the total reducing sugar and both plots in Figure 2 are not quite correct, since a high ratio (TRS/MAL) may be achieved either by acid-poor or by sugar-poor apples

In this experiment, it was shown that the main commercial Brazilian apples have an intrinsic profile of quality, and so, chemometric methods may be used to recognize this pattern in their juices. It seems reasonable to look for techniques of pattern recognition to classify apples for definitive commercial and industrial purposes.

The Principal Component Analysis (PCA) aims to group the chemical descriptors generating a new set of variables called Principal Components (PCs), which are linear combinations of the original continuous variables, completely independent. After several attempts to obtain a good classification for the categorical variables (apple varieties), the best results were found with three independent and continuous variables (Table 2). The first three principal components explain $100 \%$ of the total variance as follows: $\mathrm{PC} 1=42.50 \%, \mathrm{PC} 2=31.00 \%$, PC3 $=26.50 \%$. The plots of scores were examined and the most informative one is presented in Figure 3, which shows the PC1 against PC2, corresponding to a total of $73.50 \%$. Such a plot revealed that sample discrimination is related to the first principal component (PC1).

Figure 3 a shows the separation of the sweeter Fuji juices from the more acidic and bitter Gala juices, according to the loadings of the continuous variables, shown in Figure $3 \mathrm{~b}$. The samples Gala 14 and Fuji 10 lay down in a mixed domain, because their descriptors are so close that the model could not
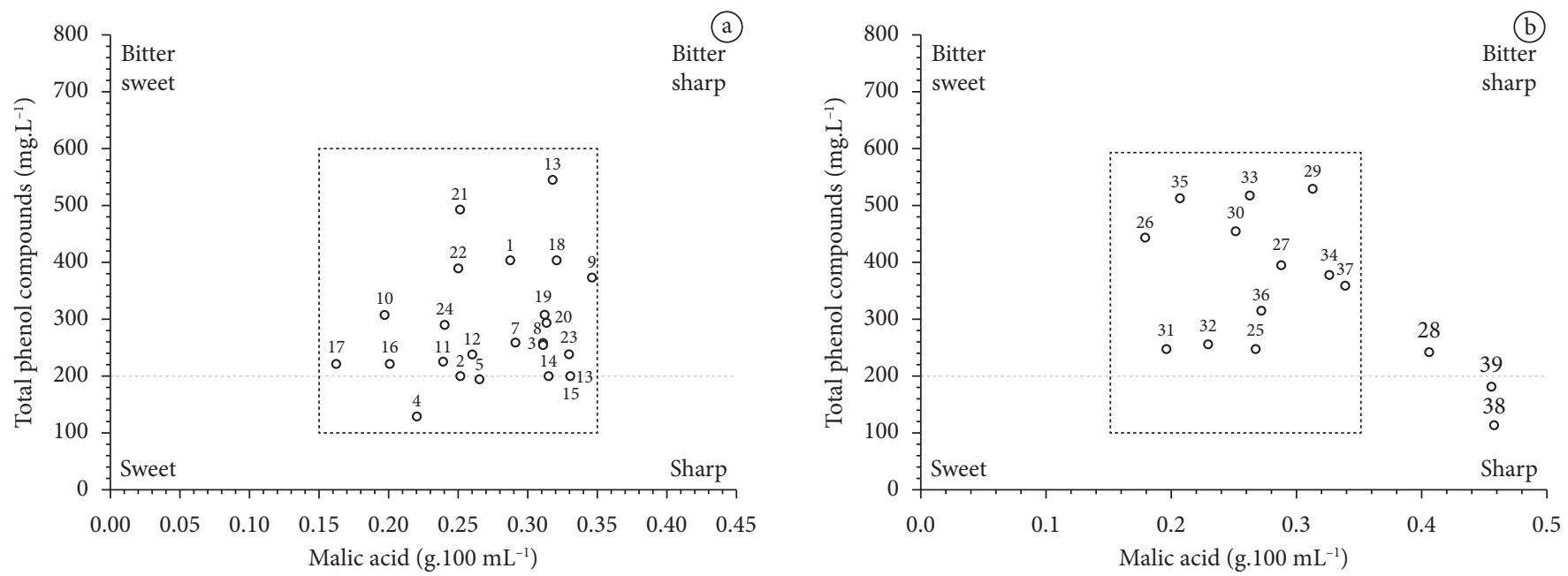

Figure 1. Scatter plot (malic acid vs. total phenolic compounds) of the samples of standard commercial Fuji and Gala apples a) discriminates their domain, and the group of authentic samples of selected commercial apples is included in such domain, b) except for three varieties, which are more acidic.
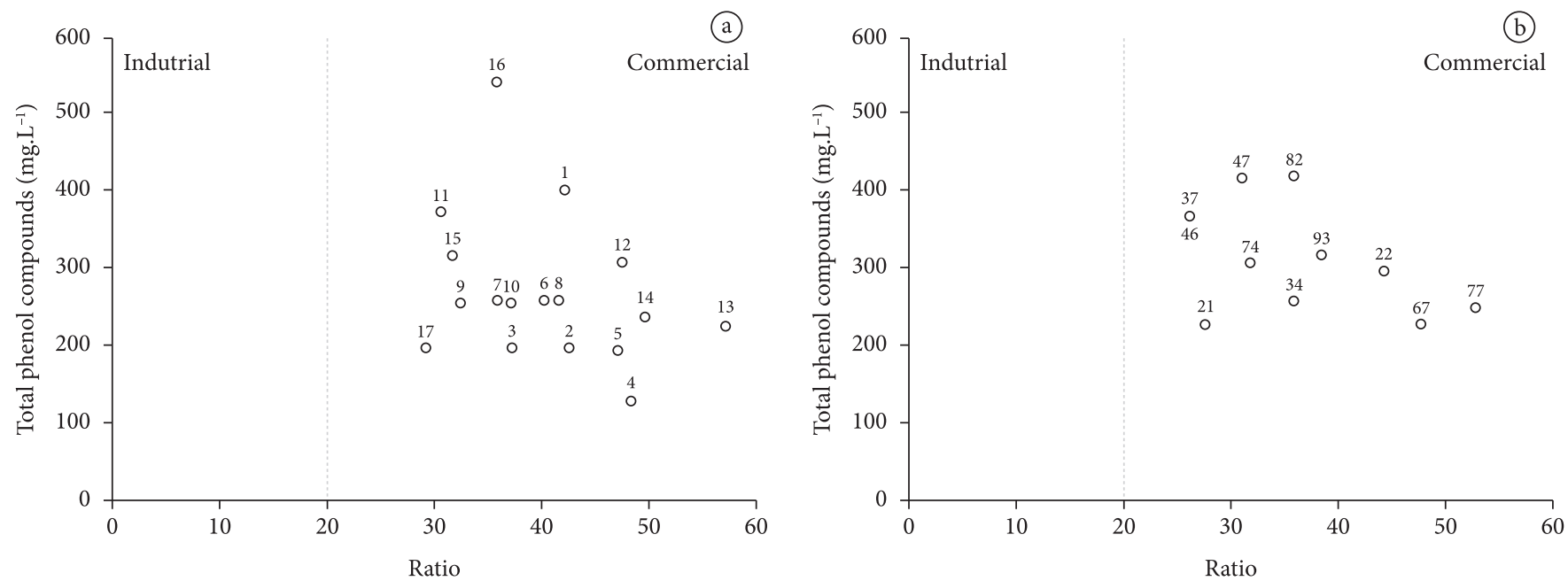

Figure 2. Scatter plot (ratio vs. total phenolic compounds) of the samples of Fuji and Gala apples a) and of the samples of commercial apple varieties $b$ ), showing that none of them have an industrial profile. 
discriminate them. The samples of Fuji juice have a descriptor with less dispersion, so its cluster is more homogeneous, once it occupies a smaller space than that of Gala juices. As there are spatial domains where 'Fuji' and 'Gala' may fit due to their similarity, the test apple juices can be qualified either as Fuji or/and as Gala.

SIMCA, related to PCA because both are based on the generation of new variables that are a linear combination of the original, may also be used for pattern recognition and classification of apple varieties. The 3D plot of PC1, PC2 and PC3 factor 3 is shown in Figure 4.

Table 4 shows the pattern recognition of the standard and of some authentic samples of apple cultivars stating its similarity for 'Fuji', for 'Gala', for both, or for none of them. In the set of authentic 'Fuji' and 'Gala' samples, none of the samples were recognized as 'Fuji', but three samples belong to Gala's domain and $21(88 \%)$ belong to the mixed domain. As expected, none of the samples became ungrouped. In the set of 15 authentic commercial samples to be modeled, none were predicted to be 'Fuji', and four were found in the 'Gala' domain, nine (60\%) were found in the mixed domain and three were excluded by the model. These results confirmed the pattern recognition of the model, and the possibility to qualify any commercial apple as Fuji and/or Gala.

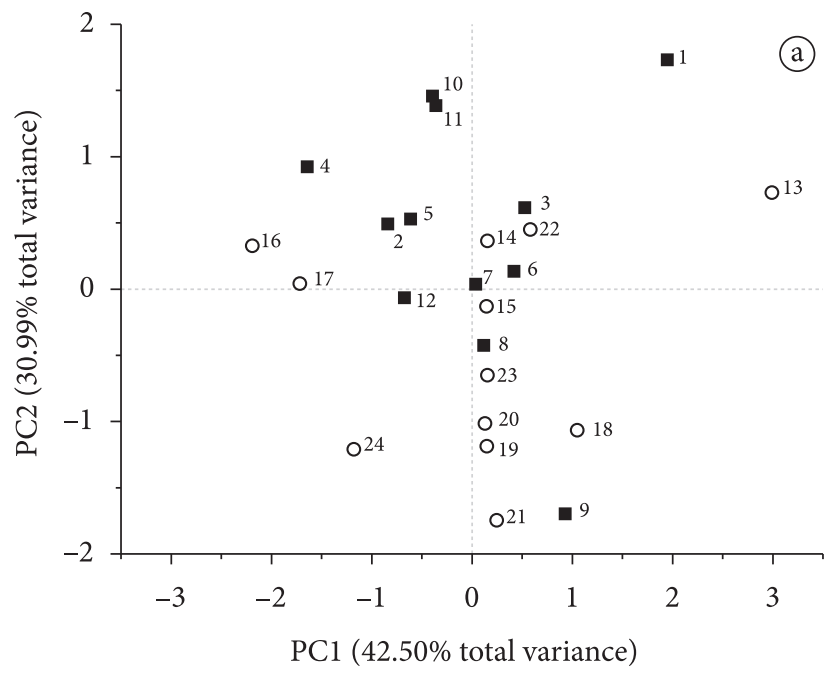

Figure 4a shows the SIMCA model for authentic Fuji and Gala samples and Figure $4 \mathrm{~b}$ shows the qualification of authentic commercial apple samples. The chemical pattern established by the chemical descriptors of 'Fuji' and 'Gala' was recognized until the $3^{\text {rd }}$ level by multivariate statistic methods (SIMCA). Curiously, none of the commercial authentic samples was qualified as 'Fuji', but four (Rainha, Imperatriz, Mollie's Delicious and Red Delicious) were categorized as 'Gala' alone. All other test samples belonged to the mixed domain, except for Princesa and Eva, which were ungrouped. It seems reasonable to quantify the selected descriptors in order to restrict the chemical pattern as that based in the Fuji and Gala domain, and to respect the borders defining the model. Table 5 shows such values, including the borders of the model.

Those values were not comparable to those reported by Czelusniak et al. (2003) on the chemical classification of samples from apples of 27 varieties, because there are not any internal reference varieties. However, if one takes into account only the fruits fitting the commercial frontier in this article, based on Fuji and Gala apples, their results are similar because $\mathrm{MAL}=0.274 \pm 0.068 \mathrm{~g} .100 \mathrm{~mL}^{-1}$ with a minimum of 0.150 and a maximum 0.340 , TRS $=10.65 \pm 1.4 \mathrm{~g} .100 \mathrm{~mL}^{-1}$, from 8.25 to 12.70 , and TPC $=286 \pm 97 \mathrm{mg} . \mathrm{L}^{-1}$, from 222 to 403 .

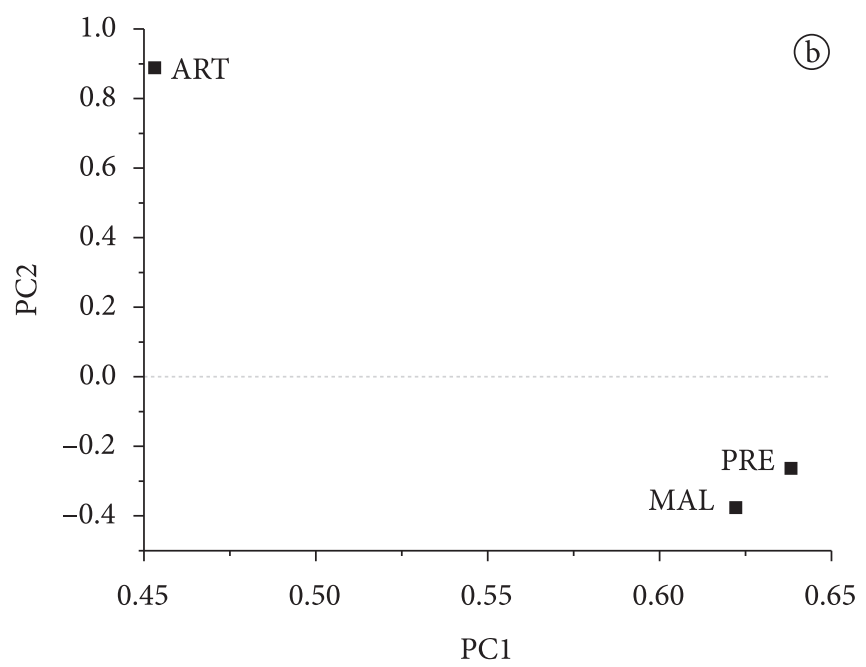

Figure 3. Score a) and loading b) plots of data concerning samples of Fuji ( $\square$ ) and Gala ( $O$ ) apple juice.

Table 4 Results of SIMCA concerning similarity to 'Fuji' or to 'Gala' apples.

\begin{tabular}{lcc}
\hline \multicolumn{1}{c}{ Domain } & Exploratory model & Predictive model \\
\hline Only Fuji & None & None \\
Only Gala & $1,13,21$ & $26,30,33,35$ \\
Either Fuji or Gala & $2,3,4,5,6,7,8,9,10,11,12,14,15,16,17,18,19,20,22,23,24$ & $25,27,28,29,31,32,34,36,37$ \\
Neither Fuji nor Gala & None & 38,39 \\
\hline
\end{tabular}



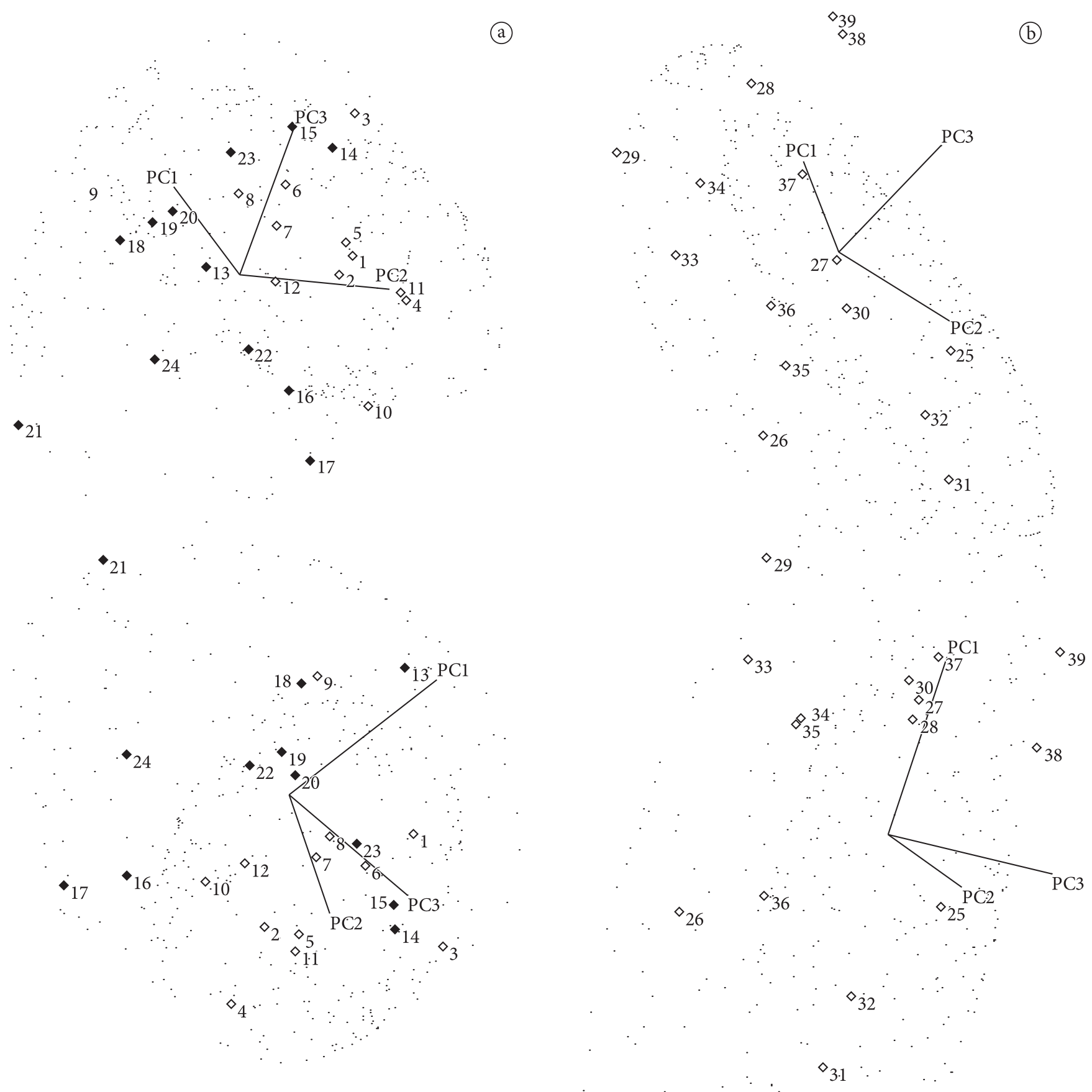

Figure 4. SIMCA model obtained with the a) descriptors of Fuji and Gala and the b) predictive classification of authentic commercial apples, from two different points of view.

Table 5. Descriptor values of the Fuji and Gala domain.

\begin{tabular}{lcc}
\hline \multicolumn{1}{c}{ Descriptors } & Average & Borders \\
\hline Malic acid (g.100 mL $\left.\mathrm{mL}^{-1}\right)$ & $0.259 \pm 0,051$ & $0.156-0.361$ \\
Total Reducing Sugars $\left(\mathrm{g} .100 \mathrm{~mL}^{-1}\right)$ & $11.38 \pm 1.574$ & $9.24-15.51$ \\
Total Phenolic Compounds $\left(\mathrm{mg} . \mathrm{L}^{-1}\right)$ & $392 \pm 107$ & $178-606$ \\
\hline
\end{tabular}

To illustrate such a chemical pattern, Figure 5 shows a box and whisker plot with a broader amplitude of the 'Fuji' and 'Gala' descriptor than that of the commercial apple juice samples and a slight exception in what concerns malic acid - the apple juices used to test the model are slightly more acidic than the standard juices. 


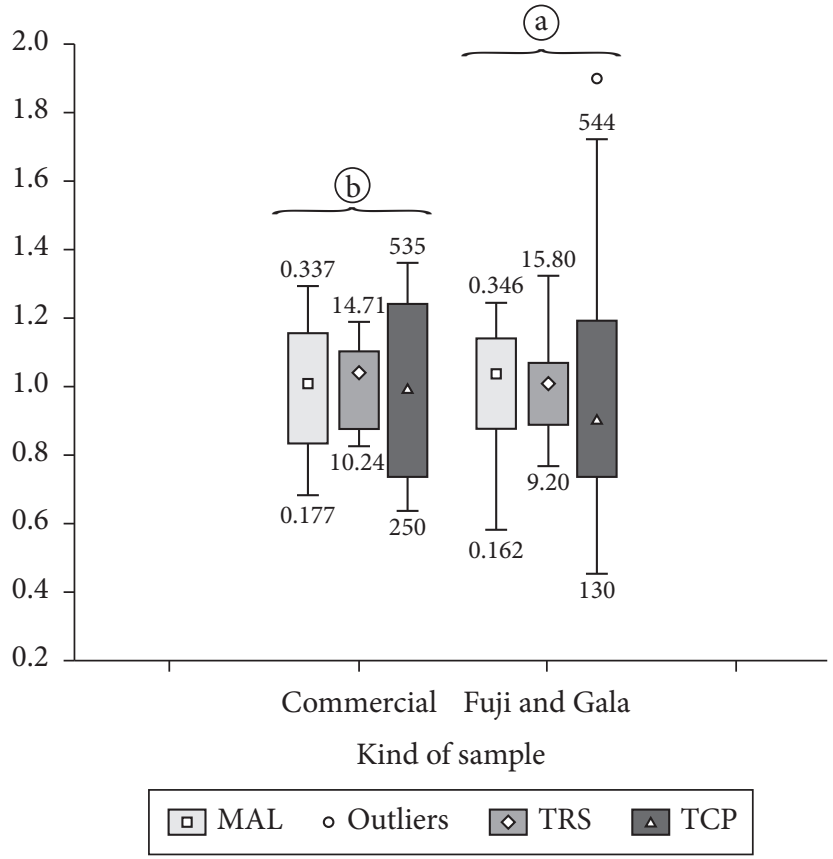

Figure 5. a) Representation of the inferior and superior normalized values of the chemical descriptors from 17 authentic commercial Fuji and Gala apples. b) Representation of the inferior and superior borders of ten authentic commercial apples that are clearly inside the volume of the Fuji and Gala borders.

\section{Conclusions}

The chemical descriptors malic acid and total phenolic compounds state the chemical pattern based on the main commercial varieties in Brazil, namely Fuji and Gala, in the domain $0.15-0.35$ g. $100 \mathrm{~mL}^{-1}$ (malic acid) and 100-500 mg. $\mathrm{L}^{-1}$ (total phenolic compounds), qualified as sweet and bittersweet apples, respectively. None of the authentic samples of apple fit the condition to be considered as industrial, with a ratio TRS/ MAL below 20.

The exploratory PCA screened and auto-scaled the best malic acid, total reducing sugar and total phenolic compound chemical descriptors to be used in the classificatory SIMCA, whose model discriminates all commercial varieties as Fuji, as Gala or as both Fuji and Gala, with 100\% correctness.

The chemical pattern of commercial apple varieties could be conventionally established and, based on Fuji and Gala apple juice, be included within the borders of malic acid $\left(\mathrm{MAL}=0.16-0.33 \mathrm{~g} .100 \mathrm{~mL}^{-1}\right)$, total reducing sugar (TRS $=9.32-13.33 \mathrm{~g} . \mathrm{mL}^{-1}$ ) and total phenolic compounds $\left(\mathrm{TPC}=130-418 \mathrm{mg} \cdot \mathrm{L}^{-1}\right)$.

\section{Acknowledgements}

The authors are deeply grateful to the Universidade Estadual de Ponta Grossa (UEPG) for the infra-structural support concerning the laboratory; to Empresa de Pesquisa Agropecuária e de Extensão Rural de Santa Catarina (Epagri) for the fruit supply used in this study, and to Conselho Nacional de Desenvolvimento Cientifico e Tecnológico (CNPq) for the financial support and scholarships at different levels.

\section{References}

ALONSO-SALCES, R. M. et al. Classification of apple fruits according to their maturity state by the pattern recognition analysis of their polyphenolic compositions. Food Chemistry, v. 93, n. 1, p. 113-123, 2005. http://dx.doi.org/10.1016/j.foodchem.2004.10.013

BARROS NETO, B.; SCARMÍNIO, I. S.; BRUNS, R. E. 25 anos de quimiometria no Brasil. Química Nova, v. 29, n. 6, p. 2006.

BLANCO-GOMIS, D. et al. Use of High performance liquid chromatographic-chemometric techniques to differentiate apple juices clarified by microfiltration and ultrafiltration. Analyst, v. 123, p. 125-129, 1998. http://dx.doi.org/10.1039/a704081d

CZELUSNIAK,C. et al. Qualidade de Maçãs Comerciais Produzidas no Brasil: Aspectos Físico-Químicos. Brazilian Journal of Food Technology, Campinas, v. 6, n. 1, p. 25-31, 2003.

FERTONANI, E. C. F. et al. Potencial da variedade joaquina para o processamento de suco clarificado e vinho seco de maçã. Ciência Tecnologia Alimentos, Campinas, v. 26, n. 2, p. 434-440, 2006. http://dx.doi.org/10.1590/S0101-20612006000200029

GONZÁLEZ, G.; PEÑA-MENDEZ, E. M. Multivariate data analysis in classification of must and wine from chemical measurements. European Food Research and Technology, v. 212, p. 100-107, 2000. http://dx.doi.org/10.1007/s002170000207

HENSCHKE, R. A maçã e o Mercosul. Revista Agropecuária Catarinense, v. 7, n. 2, p. 51, 1994.

INSTITUTO ADOLFO LUTZ - IAL. Normas Analíticas do Instituto Adolfo Lutz. 3. ed. São Paulo: IAL, 1985. vol 1.

KREUTZ, C. L. Rentabilidade da cultura da macieira cultivar Gala em duas densidades de plantio. Pesquisa Agropecuária Brasileira, v. 37, n. 3, p. 229-235, 2002. http://dx.doi.org/10.1590/S0100204X2002000300001

LEA, A. Phenolic compounds in apple juice - positive and negative effects. Fruit Processing, v. 5, n. 9, p. 281-286, 1995.

LEA, A.; DRILLEAU, J. F. Cider-making. In: LEA, A. Fermented Beverage Production. London: Blackie Academic \& Professional, 2003. p. 59-87.

MOLFETTA, F. A. et al. A structure-activity relationship study of quinone compounds with trypanocidal activity. European Journal of Medicinal Chemistry, v. 40, p. 329-338, 2005. PMid:15804532. http://dx.doi.org/10.1016/j.ejmech.2004.10.009

NELSON, N. A photometric adaptation of the Somogyi method for determination of glucose. Journal of Biology Chemistry, v. 165, p. 375, 1944.

NOGUEIRA, A. et al. Efeito do processamento no teor de compostos fenólicos em sucos de maçãs. Publicatio UEPG - Ciências Exatas e da Terra, Ciências Agrárias e Engenharias, v. 9, n. 3, p. 7-14, 2003.

NOGUEIRA, A. et al. Physicochemical and sensorial characteristics of clarified and fermented apple juice. Publicatio UEPG - Ciências Exatas e da Terra, Ciências Agrárias e Engenharias, v. 12, n. 3, p. 15-23, 2006.

PAGANINI, C. et al. Análise de aptidão industrial de seis cultivares de maçãs, considerando suas avaliações físico-químicas (dados safras de 2001/2002). Ciência e Agrotecnologia, Lavras, v. 28, n. 6, p. 1336-1343, 2004. 
SCHOBINGER, M. et al. Phenolic compounds in apple juice. Positive and negatives effects. Fruit Processing, v. 5, n. 6, p. 171-178, 1995.

SHUGAR, G. J.; BALLINGER, J. T. Chemical technician's ready reference handbook. 4th ed. New York: McGraw-Hill Professional, 1996. $972 \mathrm{p}$.

SOMOGYI, M. A new reagent for the determination of sugar. Journal Biology Chemistry, n. 160, p. 61-68, 1945.

TANNER, H.; BRUNNER, H. R. Getränke AnalytikUntersuchungsmethode für die labor - und Betriebspraxis. Wädenswill: Helles, 1985
WORLD apple review. 2008 ed. Pullman: Ed. Belrose Inc., 2008. 138 p. WOSIACKI. G. et al. Quality profile of samples of 103 apple cultivars harvested in Brazil from 1982 to 2004. Acta Alimentaria, v. 37, n. 1, p. 9-22, 2006.

WOSIACKI, G. et al. Apple varieties growing in subtropical áreas. The situation in Santa Catarina - Brazil. Fruit Processing, v. 12, n. 1, p. 19-28, 2002.

WOSIACKI, G. et al. Estabilidade do suco clarificado de maçã. Parte I - Processo de obtenção do suco de maçã. Arquivos de Biologia e Tecnologia, v. 32, n. 4, p. 775-786, 1989. 